\title{
PENGARUH METODE ICE BREAKING TERHADAP MINAT BELAJAR SISWA DI KELAS V SD NEGERI 26 DOMPU
}

\author{
Ilham, Supriaman \\ STKIP Yapis Dompu, STAI Al Amin Dompu \\ Email: ilhamtarbiyah@gmail.com \\ supriamandiman40@gmail.com
}

\begin{abstract}
Abstrak:
Tujuan dari penelitian ini adalah untuk mengetahui cara mencairkan suasana dalam proses pembelajaran yang monoton pada siswa kelas V SD Negeri 26 Dompu tahun pelajaran 2021/2022. Penelitian ini merupakan penelitian deskriptif kuantitatif dengan objek penelitian siswa kelas V serta guru mata pelajaran. Instrumen yang digunakan dalam penelitian ini adalah pedoman observasi, wawancara atau angket dan dokumentasi. Prosedur pengumpulan data yang digunakan adalah observasi, wawancara dan dokumentasi. Sedangkan sumber data yang digunakan dalam penelitian ini adalah 3 orang yaitu siswa kelas $\mathrm{V}$, guru mata pelajaran dan kepala sekolah Negeri 26 Dompu. Penerapan ice breaking bertujuan untuk memecahkan kebekuan, kekisruhan, dan kejenuhan suasana sehingga mencair dan suasana pembelajaran dapat kembali ke keadaan semula (lebih kondusif). Ada banyak jenis ice breaking, namun peneliti hanya mengambil beberapa jenis ice breaking yaitu jenis, permainan, lagu, tepuk tangan dan juga humor. Diantara jenis ice breaking yang diterapkan oleh guru mata pelajaran adalah jenis ice breaking (lagu dan tepuk tangan). Dampak penerapan ice breaking dapat merangsang siswa dalam belajar karena siswa diajak belajar sambil bermain sehingga tidak merasa terpaksa untuk belajar. Sehingga dapat dikatakan bahwa proses pembelajaran dengan menerapkan ice breaking dapat membuat siswa senang dan lebih menyenangkan saat melakukan proses pembelajaran.
\end{abstract}

Kata Kunci: Metode Ice Breaking dan Minat Belajar,

\section{PENDAHULUAN}

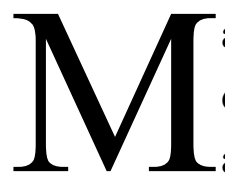

anusia adalah makhluk yang dikenal memiliki akal yang digunakan untuk berfikir, belajar dan juga berkarya. Dengan

akal, manusia bisa menciptakan sesuatu yang mungkin tidak dimiliki oleh makhluk lainya. Pendidikan adalah salah satu jalan untuk mengacah akal fikiran manusia. Oleh karena itu pendidikan tidak boleh 
menekan dan memenjarakan peserta didik dengan cara menciptakan pembelajaran yang menyenangkan sehingga peserta didik merasa nyaman, dan senang dengan suasana pembelajaranya.

Dari hasil pengamatan peneliti dilapangan bahwa banyak sekali sekolah-sekolah yang membelenggu siswa dan tidak mengutamakan keaktifan peserta didik ketika proses pembelajaran berlangsung. Para pendidik yang kurang mengerti hakekat mengajar akan membuat suasana belajar menjadi kurang kondusif, sebagian guru sering kali beranggapan bahwa melaksanakan pekerjaan mengajar adalah suatu yang bersifat rutinitas belaka, asal sudah membuat persiapan mengajar beserta perangkat pembelajarannya dianggap sudah cukup, tanpa memperhatikan komponen lainya, yaitu seperti karakteristik siswa ketika sedang belajar (termasuk kondisi siswa saat belajar) sehingga hasil belajar siswa menjadi tidak optimal. Dan pada hakekatnya pendidikan itu sebagai fasilitator untuk menfasilitasi peserta didik dalam membangun pemahamanya tentang materi yang sedang dipelajari. Peserta didik sangat dituntut untuk belajar sehingga dapat merubah tatanan kehidupan baik dalam lingkungan masyarakat dan sebagainya.

Menurut penelitian Miswar dalam bukunya Dollar dan Miller menegaskan bahwa efektifitas prilaku belajar dipengaruhi oleh empat hal, yaitu adanya motivasi, perhatian dan tahu sasaran, usaha, serta evaluasi dan pemantapan hasil. (Miswar, 2017). Kadar motivasi, perhatian, dan usaha peserta didik dalam belajar dipengaruhi banyak hal, salah satu yang cukup mendasar adalah suasana belajar yang kurang kondusif akan memberikan pengaruh psikis. Suasana pembelajaran yang membosankan akan menimbulkan kejenuhan sehingga peserta didik mengalami keletihan. Pada saat seperti inilah peserta didik mengalami penurunan daya ingat. Driver and Bell dalam bukunya Leo Sutrisno mengatakan, Belajar diartikan sebagai suatu proses aktif menyusun makna melalui semua interaksi dengan lingkungan dan membangun hubungan antara konsepsi yang telah dimiliki dengan fenomena yang telah dipelajari. (Suyono \& Hariyanto, 2011). Proses pembelajaran pada satuan pendidikan diselenggarakan secara interaktif, inspiratif, menyenangkan, menantang, memotivasi siswa untuk berpartisipasi aktif, 
memberikan ruang gerak yang cukup bagi prakarsa, kreatifitas dan kemandirian, sesuai dengan bakat, minat, dan perkembangan fisik serta psikologi siswa. (Sunarto, 2012). Keberhasilan suatu pendidikan salah satunya ditentukan oleh seorang guru dan siswa selama pembelajaran berlangsung. Pada dasarnya guru di tuntut untuk melakukan pembelajaran secara efektif sehingga tidak membosankan dan siswa dituntu aktif dan berprestasi dalam pembelajaran yakni adanya dorongan dan motivasi belajar dari guru dalam memperoleh pembelajaran. Seorang guru memiliki target kurikulum yang dibebankan oleh pihak sekolah oleh karena itu guru harus menyampaikan kepada siswa dengan kurun waktu yang singkat. Sehingga siswa mudah jenuh dan kurang bersemangat dalam mengikuti pembelajaran.

Ice breaking adalah permainan atau kegiatan yang berfungsi untuk mengubah suasana kebekuan dalam kelompok. (Said M, 2010). Sedangkan menurut Adi Soenano ice breaking merupakan cara tepat untuk menciptakan suasana kondusif. Penyatuan pola pikir dan pola tindak kesatu titik perhatian adalah yang bisa membuat suasana menjadi terkondisi untuk dinamis dan fokus. (Soenarno adi, 2005). Berdasarkan beberapa pendapat ice braking dapat diartikan sebagai kegiatan yang berfungsi untuk menghilangkan kebekuan pada peserta didik atau mencairkan suasana sehingga bisa lebih semangat lagi dalam menerima pelajaran.

Hasil belajar merupakan prestasi peserta didik secara keseluruhan yang menjadi indikator kompetensi dasar dan derajat perubahan prilaku yang bersangkutan. (Mulyana, 2009). Sedangkan menurut Nana sudjana bahwa penilaian hasil belajar adalah proses pemberian nilai-nilai terhadap hasil-hasil belajar pada kriteria tertentu. Hal ini mengisyaratkan bahwa objek yang dinilai adalah hasil belajar siswa. Pada hakekatnya mencangkup pada bidang kognitif, afektif, dan psikomotorik. (Sudjana Nana, 2012). Berdasarkan beberapa pendapat bahwa hasil belajar siswa merupakan kemampuan yang dimiliki oleh siswa itu sendiri dalam mengikuti pelajaran. Sedangkan kemampuan belajar yang dimiliki oleh siswa berupa pengetahuan, sikap, tanggung 
jawab dalam menjalankan tugas yang diberikan oleh guru, dan juga keterampilan dalam memahami hasil belajarnya.

Berdasarkan hasil observasi yang peneliti amati di Minat belajar siswa pada kelas V SD Negeri 26 Dompu, kelemahan peserta didik adalah malasnya peserta didik untuk berfikir, kurangnya kreativitas dalam menerima mata pelajaran di kelas. Akibatnya peserta didik menjadi fakum, acuh terhadap penerimaan pengetahuan pada saat proses belajar sehingga mempengaruhi hasil dan motivasi belajar peserta didik. Di kehidupan seharian juga, sering kali kita dihadapkan dengan berbagai masalah. Berdasarkan permasalahan tersebut Sehingga mendorong penulis untuk menggunakan atau menerapkan metode pembelajaran metode Ice Breaking kiranya dapat merangsang peserta didik untuk termotivasi memecahkan masalah dalam kesehariannya. Berdasarkan pemikiran tersebut maka penulis terdorong untuk melakukan penelitian pengaruh Pengaruh metode ice breaking terhadap minat belajar siswa pada kelas V SD Negeri 26 Dompu.

\section{TINJAUAN TEORI}

Ice breaking merupakan pemecahan masalah atau bisa juga disebut dengan usaha untuk mencairkan suasana tidak kaku, nyaman dan santai. Hal ini dilakukan agar materi-materi yang disampaikan kepada siswa bisa diterima dengan baik. Menurut Suryati ice breaking merupakan salah satu aktivitas untuk mengalihkan situasi dari dari membosankan, mengantuk menjadi menyenangkan, bersemangat, rileks dan tidak membuat mengantuk sehingga suasana belajar lebih mencairdan lebih kondusif dan memiliki pengaruh yang signifikan. (Suryati, 2014).

Ada beberapa manfaat ice breaking diantaranya adalah menghilangkan kejenuhan peserta didik, kurang fokus, kelelahan untuk itu perlunya melakukan rutinitas pembelajaran dengan melakukan aktivitas gerak bebas sehingga peserta didik bisa dengan mudah menerima ilmu, ada beberapa manfaat lainya dari ice breaking ini diantaranya adalah. (Achmad Fanani, 2010) Manfaat ice breaking antara lain; melatih berpikir secara kreatif, mengoptimalkan otak dan 
kreativitas peserta didik, melatih konsentrasi, berani dan tidak takut salah dan melatih jiwa kepemimpinan.

Hilgart memberikan rumusan mengenai minat sebagai berikut "Interest is persistingtendency to pay attention to and enjoy some activity or content" minat adalah kecenderungan yang tetap untuk memperhatikan dan mengenang beberapa kegiatan. kegiatan yang diminati seseorang, diperhatikan dengan terus-menerus dengan yang disertai dengan rasa senang. Maka berbeda dengan perhatian sifatnya yang sementara atau tidak dalam waktu yang lama dan belum tentu di ikuti dengan perasaan senang, sedangkan minat selalu di ikuti dengan perasaan senang dan dari situ diperoleh kepuasan. Minat yang besar pengaruhnya terhadap pelajaran, karena bila bahan pelajaran yang dipelajari tidak sesuai dengan minat peserta didik, maka peserta didik tidak akan belajar dengan sebaik-baiknya karena tidak ada daya tarik bagi dirinya. Ia malu-malu belajar ia tidak akan memproleh kepuasan dari pelajaran tersebut. (Slameto, 2013).

Mengembangkan minat terhadap sesuatu pada dasarnya merupakan membantu siswa untuk melihat bagaimana hubungan antara materi yang diharapkan untuk dipelajarinya dengan dirinya sendiri sebagai individu. Proses ini berarti menunjukkan pada siswa bagaimana pengetahuan atau kecakapan tertentu mempengaruhi dirinya, melayani tujuan-tujuannya, memuaskan kebutuhan-kebutuhannya. Jika peserta didik menyadari bahwa belajar untuk mencapai beberapa tujuan yang dianggap sangat penting, dan bila siswa melihat bahwa hasil dari pengalaman belajarnya akan membawa kemajuan bagi dirinya, kemungkinan besar dia akan berminat dan termotivasi untuk mempelajarinya. (Slameto,2013).

Dari penjelasan diatas dapat disimpulkan bahwa pentingnya bagi pendidik untuk menciptaan pelajaran yang menarik agar lebih mudah dipelajari dan menanamkan kecintaan pada pelajaran tersebut sehingga peserta didik bisa lebih enjoy dan semangat ketika menerima pelejaran sebab, peserta didik yang kurang minat dalam belajar tentunya akan membuat peserta didik tidak bisa belajar dengan sebaik-baiknya karena tidak adanya minat, untuk itu sebagai pendidik perlu 
memperhatikan hal ini dengan menjelaskan hal-hal yang menarik bagi kehidupan serta hal-hal yang berhubungan dengan cita-cita serta yang berkaitan dengan bahan-bahan yang dipelajari.

1. Pengaruh Minat Terhadap Kegiatan Belajar Siswa

Minat merupakan faktor yang sangat penting dalam kegiatan peserta didik. Dalam kegiatan belajar tidak sesuai dengan minat peserta didik maka kemungkinan berpengaruh tidak baik terhadap hasil belajar perserta didik tersebut. Dengan adanya minat tersebut serta tersedianya rangsangan yang ada sangkut pautnya pada diri peserta didik maka peserta didik bisa memproleh kepuasan batin dari kegiatan tersebut. Dalam dunia pendidika disekolah, minat memegang perana penting saat belajar karena minat adalah suatu kekuatan motivasi yang menyebabkan seseorang memusatkan perhatiannya, pada suatu benda atau kegiatan tertentu. Maka demikian minat merupakan faktor yang sangat penting untuk menunjang kegiatan belajar peserta didik. Dalam kenyataan ini juga diperkuat oleh pendapat Sardiman yang menyatakan bahwa proses belajar itu akan berjalan lancar bila disertai dengan minat. (Susanto Ahmad, 2013).

Maka dilihat dari uraian diatas semakin jelas bahwa minat akan berdampak pada kegiatan yang dilakuka seseorang. Dlam hubungan dengan kegiatan belajar. Minat tertentu memungkinkan akan berpengaruh pada hasil belajar peserta didik, hal ini ditunjukan pada kegiatan peserta didik terhadap sesuatu yang diminati. Hartono mengatakan bahwa minat memberikan sumbangan besar pada keberhasilan peserta didik. Bahan pelajaran, maupun metode pembelajaran yang tidak sesuai dengan minat peserta didik akan menyebabkan hasil belajartidak optimal dan tidak sesuai dengan apa yang diinginkan. Di dalam kegiatan belajar, juga dalam proses pembelajaran, maka tentunya minat yang diharapkan merupakan minat yang timbul dengan sendirinya dari diri peserta didik itu sediri, tanpa paksaan dari luar, supaya peserta didik bisa belajar lebih aktif dan koefisien. Akan tetapi, pada kenyataanya tidak jarang pserta didik akan mengikuti pelajaran dikarenakan adanya suatu kewajiban, sementara peserta didik tersebut tidak menaruh minat pada pelajaran 
tersebut. Yang baik itu seharusnya anak mengetahui minatnya, karena tanpa diketahui apa yang diminatinya, maka tujuan belajar yang diinginkan tidak akan tercapai dengan maksimal.( Susanto Ahmad, 2013)

2. Tinjauan Tentang Belajar

Wahyu yang pertama yang diturunkan oleh Allah swt kepada nabi muhammad saw dalam qur'an surah Al-Alaq ayat 1-5 memberikan isyarat bahwa islam sangat memperhatikan soal belajar dalam kontek menuntut ilmu sehingga implementasinya belajar itu wajib menurut islam baik itu laki-laki maupun perempuan. (Nurjana Syarifan M.A, 2015). Persprektif islam makna belajar bukan hanya sekedar merubah prilaku. Konsep belajar dalam islam merupakan konsep belajar yang ideal karena sesuai dengan nilai-nilai ajaran islam. ( Syarifan Nurjana M.A,2015:14)

Dan menurut Wina Sanjaya, belajar adalah proses berpikir. Belajar berfikir menekankan pada proses mencari dan menemukan pengetahuan melalui interaksi antara individu dengan lingkungan. (Wina Sanjaya, 2010). Mayer, belajar adalah serangkaian kegiatan jiwa raga untuk memperoleh suatu perubahan tingkah laku sebagai hasil dari pengalaman individu dalam interaksi dengan lingkungan yang menyangkut kognitif dan efekti. (Banny A Pribadi, 2019). Carl Rogers, setiap individu itu mempunyai cara belajar yang berbeda dengan individu yang lain oleh karena itu, strategi dan pendekatan dalam proses belajar dan mengajar hendaklah dirancang dan disusun mengikuti khendak dan perkembangan emosi peserta didik. (Carl Roger, 2012)

Dari beberapa pendapat diatas disimpulkan bahwa belajar merupakan salah satu proses untuk bisa mendapatkan pengetahuan karena adanya interaksi aktif antara individu dengan lingkungan yang menghasilkan perubahan-perubahan yang bersifat relatif.

\section{METODOLOGI PENELITIAN}

Pendekatan dalam penelitian ini adalah kuantitatif, biasanya metode yang digunakan ialah pemanfaatan dokumen, wawancara dan 
eL-Muhbib

Jurnal Pemikiran dan Penelitian Pendidikan Dasar

ISSN 2614-1051 Volume 5 Nomor 2 Desember 2021

pengamatan lingkungan sekitar. Penelitian ini dianalisis menggunakan pearson product moment yang merupakan salah satu teknik untuk mencari korelasi antar dua variable yang kerap kali digunakan. Teknik korelasi ini dikenal dengan istilah teknik korelasi pearson.Penelitian ini dilaksanakan di V SD Negeri 26 Dompu, yang berlokasi di Jl.Sumbawa desa O'o kec. Dompu kab. Dompu dan waktu penelitian akan dilaksanakan pada semester genap tahun ajaran 2021/2022.Penelitian ini menggunakan populasi dan sampel. (Dr.Sugiyono, 2019).Populasi yang digunakan dalam penelitian ini adalah siswa kelas V SD Negeri 26 Dompu. Sedangkan metode pengumpulan data dalam penelitian ini adalah observasi, angket dan dokumentasi. (Sugiyono, 2018).

\section{PEMBAHASAN}

Penelitian ini bertujuan untuk mengetahui " pengaruh metode ice breaking terhadap minat belajar siswa kelas V SD Negeri 26 Dompu". Penelitian ini menggunakan dua variabel yaitu variabel bebas (metode ice breaking) dan variabel terikat ( minat belajar siswa). Pada penelitian ini peneliti mengambil satu kelas sebagai sampel yaitu keles V-A dengan jumlah peserta didik sebanyak 28 . Kemudian dibagikan 30 item angket untuk mengetahi minat belajar siswa dengan menggunakan metode ice breaking dan setelah dilakukan test item yang valid adalah 20 item. Metode ice breaking merupakan metode pembelajaran aktif dan menarik, selain membuat peserta didik lebih aktif metode ini juga sangat berguna untuk menghilangkan rasa bosan, jenuh, dan malasnya siswa dalam belajar.

Berdasarkan penelitian yang telah dilakukan peneliti di kelas VA dengan menggunakan metode ice breaking diawali dengan mengatur tempat duduk peserta didik kemudian peserta didik diminta berhitung 1 sampai dengan 10. Peserta didik mengikuti intruksi yang guru berikan adalah peserta yang kebetulan mendapatkan hitungan kelipatan 3 yaitu, $3,6,9$, harus mengganti dengan kata blang, blang, blang. Peserta yang salah dalam permainan ini harus keluar dari permainan dan diberi tugas untuk menjawab pertanyaan dari guru. peserta yang lain akan 
membetulkan angka yang salah tadi. Lalu permainan akan berulang terus menerus disela pembelajaran.

Dalam pembelajaran ice breaking ini peserta didik di latih agar lebih fokus belajar tanpa harus merasa jenuh, atau bosan. Metode pembelajaran ice breaking di harapkan supaya peserta didik bisa lebih meningkatkan keatifan dan motivasi dalam belajar. Dalam metode pembelajaran ice breaking peserta didik tidak dibagi dalam kelompok melaikan peserta didik bekerja sendiri-sendiri, sehingga tidak memungkinkan mereka untuk mengobrol saling mengandalkan satu dengan yang lain dan beraktivitas di luar pembelajaran. Dengan begitu peserta didik akan lebih cepat memahami materi pembelajaran yang ada. Metode ini sangat sesuai dengan usis peserta didik peralihan dari kelas rendah ke kelas tinggi, dimana anak kelas usia rendah lebih senang dengan cara belajar sambil bermain tetapi tetap fokus pada materi yang diberikan guru guna untuk mencapai tujuan pembelajaran.

Setiap metode pembelajaran memiliki kekurangan dan kelebihan masing-masing, jadi akan lebih baik ketikan akan memilih metode pembelajaran menyesuaikan dengan permasalahan yang di alami sehingga pembelajaran bisa berjalan dengan normal dan tentu dapat meningkatkan minat peserta didik. Dalam penelitian ini ada dua kali pertemuan, pertemuan pertama melihat bagaimana metode yang diajarkan oleh guru mapel aqidah akhlak dan hal ini dilakukan pada tanggal 5 Oktober 2021 jam 08.30-10.00, kemudian pada tanggal 6 Oktober 2021 jam 08.15-10.00 peneliti mencoba melakukan penerapan ice breaking sekaligus melakukan sesi wawancara dengan guru mapel, siswa dan juga kepala sekolah.

Setiap hari yang sama peneliti meminta jam tambahan kepada wali kelas untuk melakukan post test di kelas V-A, Permintaan peneliti untuk meminta jam tambahan adalah guna untuk meng-efektifan waktu penelitian agar tidak terganggu dengan dilakukannya post test. Dan permintaan waktu yang diminta disetujui oleh wali kelas.

Berdasarkan hail perhitungan dihasilkan nilai rata-rata kelas VA adalah dengan jumlah responden 28 siswa.Hasil penelitian menunjukan bahwa rata-rata minat belajar siswa denga menggunakan 
metode ice breaking. Hal ini ditunjukan dengan program hitungan dengan spss versi 24 untuk menguji normalitas kelas V-A.Hasil hitungan menunjukan bahwa nilai-nilai signifikan 247 ini berarti nilai $t_{\text {tabel }}$ lebih besar dari nilai $t_{\text {tabel }}$ pada taraf signifikan $5 \%$ sehingga $\mathrm{H}_{\mathrm{o}}$ di tolak. Dengan ini di simpulkan bahwa minat belajar siswa dengan menggunakan metode ice breaking lebih tinggi dibandingkan dengan belajar menggunkan metode pembelajaran lain.

\section{SIMPULAN}

Berdasarkan hasil analisis data dan uji hipotensis pada bab IV, penulis menyimpulkan bahwa ada pengaruh metode pembelajaran ice breaking dengan minat belajar siswa kelas V-A di SD Negeri 26 Dompu, hal ini terlihat hasil angket pada minat belajar siswa dengan menggunakan metode pembelajaran ice breaking lebih tinggi dari pada menggunakan metode lainnya. Hasil penelitian menunjukan bahwa ratarata minat siswa dengan menggunakan metode ice breaking lebih tinggi dari pada rata-rata nilai minat dengan menggunakan metode lain.

\section{DAFTAR PUSTAKA}

Ahmad Fanani. 2019.Ice Breaker Dalam Proses Belajar Mengajar, Jurnal Pendidikan.

Adi Soenarno. 2005.Ice Braker Permainan Akratif-Edukatif,Yogyakarta. Andi Offset Ahmad susanto. , 2013.Teori Belajar dan Pembelajaran di Sekolah Dasar, Jakarta,Kencana.

Arif B Iskandar. 2018. Materi Dasar Islam, Bogor: Al-Azhar Press.

Depag RI, Kurikulum 2004, Direktorat kelembagaan agama islam, Jakarta.hal Ice Breaker Dalam Pembelajaran Aktif,Surakarta,Yuma.

M.Said. 2010.Ice Breaker Games-Kumpulan Pengunggah Semangat, Yogyakarta, Ando Offcet.

Mulyasa. 2009.Implementasi Kurikulum Tingkat Satuan Pendidikan Kemandirian Guru Dan Kepala Sekolah,Jakarta, Bumi Aksara.

Miswar. 2017. Ice Breaker Pembelajaran Aktif,

Nana Sudjana. 2012.Penilaian Hasil Proses Belajar Mengajar,Bandung, PT. Remaja, Rosda Karya.

Slameto. 2013.Belajar Dan Faktor-Faktor Yang Mempengaruhinya, 2015 Jakarta, Rineka Cipta. 
Sugiyono. 2014. Metode Penelitian Kuantitatif,Kualitatif dan R N D,Bandung, Alfabeta.

Suharsimi Arikunto. 2007.Manajemen Penelitian,Jakarta, Rieneka Cipta. Suharsimi Arikunto. 2013. Prosedur Penelitian Dalam Suatu Pendekatan Praktek,Jakarta: Rineka Cipta.

Sunarto. 2012.Ice Breaker Dalam Pembelajaran Aktif,Surakarta, Cakrawala Media.

Suryati.Pengaruh Metode Ice Breaking Terhadap Motivasi Belajar Kimia Siswa Kelas X di SMA 10 Negri Yogyakarta Tahun Ajaran 2013/2014,Yogyakarta, Skripsi.

Suyono dan Hariyanto. 2011. Belajar Dan Pembelajaran,Bandung, PT. Rosda Karya Officet.

Syarifan Nurjanan. 2015. Psikologi Belajar, Ponorogo, Wade Group.

Wina Sanjaya. 2010. Kurikulum Dan Pembelajaran, Jakarta,Kencana.

Wina Sanjaya. 2010.Strategi Pembelajaran Berorientasi Standar Proses Pendidikan,Jakarta,Kencana, 2010. 